\title{
Lessons Learnt: Changes in the Methodology of the Entrepreneurial Discovery Process in Defining the Priorities of Hungarian Smart Specialisation Strategies
}

\author{
Zoltán Birkner ${ }^{1,2}$, Ádám Mészáros ${ }^{1,3, *}$ and István Szabó ${ }^{1}$ \\ 1 National Research, Development and Innovation Office, 1077 Budapest, Hungary; \\ zoltan.birkner@nkfih.gov.hu (Z.B.); istvan.szabo@nkfih.gov.hu (I.S.) \\ 2 Institute of Applied Economics, University of Pannonia, 8800 Nagykanizsa, Hungary \\ 3 Institute of Enterprise Development, Corvinus University of Budapest, 1093 Budapest, Hungary \\ * Correspondence: adam.meszaros@nkfih.gov.hu; Tel.: +36-303862913
}

\section{check for} updates

Citation: Birkner, Z.; Mészáros, Á.; Szabó, I. Lessons Learnt: Changes in the Methodology of the

Entrepreneurial Discovery Process in Defining the Priorities of Hungarian Smart Specialisation Strategies. Sustainability 2021, 13, 12695. https:// doi.org/10.3390/su132212695

Academic Editors: João Carlos Correia Leitão and Dina Batista Pereira

Received: 6 October 2021

Accepted: 14 November 2021

Published: 17 November 2021

Publisher's Note: MDPI stays neutral with regard to jurisdictional claims in published maps and institutional affiliations.

Copyright: (c) 2021 by the authors. Licensee MDPI, Basel, Switzerland. This article is an open access article distributed under the terms and conditions of the Creative Commons Attribution (CC BY) license (https:// creativecommons.org/licenses/by/ $4.0 /)$.

\begin{abstract}
This study shows how one of the fundamental methods of designing and implementing the Smart Specialisation Strategy (S3), the Entrepreneurial Discovery Process (EDP), was applied in the period of 2014-2020 and how, taking accrued experience into account, it has been adjusted in the new planning cycle in Hungarian practice. Based on Hungarian strategies and other policy documents, international and Hungarian literature, the study shows that although the involvement of relevant actors in strategic planning and prioritising was achieved in both cycles, the nature of the actors' participation differed fundamentally in the two periods. We found that learning from the experience of planning the S3 for 2014-2020, the design of the 2021-2027 strategy required improving the focus of priorities, validating priorities and creating an institutional system capable of making EDP continuous during the cycle 2021-2027, in line with the European Commission's expectations. We concluded that a well-functioning EDP methodology is an essential part of the substantive realisation of an S3 that can be dynamically shaped according to the challenges.
\end{abstract}

Keywords: innovation policy; smart specialisation strategy; entrepreneurial discovery process

\section{Introduction}

Smart specialisation strategies (S3) have introduced a radically new element into the practice of innovation policy (which, until the implementation of S3, has been largely managed in a top-down manner), as these strategies do not set targets on their own, but rather take into account the capabilities of actors through the so-called entrepreneurial discovery process (EDP) [1-3]. This new type of process has enabled innovation actors to play a key role in setting priorities for innovation policy. The methodology of the EDP and prioritisation can be considered key elements of the smart specialisation strategy. The aim of these methods is to select new directions that will enable the region to start the process of modernisation; instead of supporting the development of a specific innovative product or technology, the goal is to identify an area whose development through innovation can put the region on a new growth path in the future [4].

The paper has two major aims. First, we analyse the methods of EDP in the design and implementation of Hungarian smart specialisation strategies in the programming periods of 2014-2020 and 2021-2027. The second objective is to show how the experiences of the first period affected the formation (the design and the planned implementation) of the strategy for the new period. Our scope was to evaluate the role of EDP in the prioritisation of these strategies-the analysis of the results of these strategies and related policy instruments was not part of our research project. 


\subsection{The Role of Smart Specialisation in the Innovation System}

For much of its history, innovation policy was a top-down policy, but from the 1970s, the changed political, economic and social expectations (easing tensions between superpowers, halting economic growth, facing new social problems) led to new challenges for innovation players, entailing a move from a military innovation system [5] to a social innovation system [6,7].

This led to the appearance of approaches in innovation policy that no longer consider individual actors to be the units of analysis and policy intervention, but rather, the whole array of actors and their entire system. The concept thus introduced-the national innovation system-is, therefore, more than just the group of actors in a given country [8]; interactive learning and interactions between the actors are also important parts of it [9]. The original concept of the national innovation system [10] argues that both national and regional systems are important entities, they have their own national or regional characteristics, in spite of the trends of globalisation [11]. Meanwhile, the concept of a sectoral system of innovation [12] and technological systems [13] was developed, highlighting the complexity of innovation systems.

Inzelt and Bajmóczy [6] (p. 11), aligning the approaches provided by international literature cited above, defined the national innovation system as "the range of knowledgeproducing, knowledge-disseminating and knowledge-utilizing institutions that contribute individually and collectively to the development and spillover of new technologies. The capabilities of individual institutions and the relationship systems between them determine the innovative performance of companies operating in a region or in a nation". Another important element of the definition is that these institutions constitute the framework within which governments develop and implement their policies that promote the innovation process. This definition explicitly indicates that innovation policy does not set objectives on its own, but takes into account the capabilities of actors as well.

From then on, directions for examining regional innovation systems started to gain more attention and their regulation was also analysed [14]. The premise was that innovations are largely generated between geographically close actors and that the efficiency of cooperation between actors can be significantly increased by geographical proximity. Therefore, a new type of economic impact model was developed (GMR: geographic macro and regional economic impact model) to estimate the economic effects of policy interventions, based on the characteristics of the given region $[15,16]$. Today, the regional approach to the innovation system has become canonised in several aspects: smart specialisation strategies are based on it, and the European Commission (EC) has regularly published the Regional Innovation Scoreboard since 2009 [17], which measures regional innovation performances.

The well-known triple, quadruple and quintuple helix models [18-20] have also highlighted the significance of interaction and cooperation between actors of the innovation system. As a result, it has become necessary to channel the views of non-state actors into the policy on an increased level. Therefore, a mechanism capable of addressing this in a methodologically sound manner was also needed. Concurrently with the paradigm shift in innovation policy, reducing territorial disparities has become an important goal in the European Union, which is becoming increasingly heterogeneous in terms of socio-economic development.

As innovation became more important in economic development [21,22], regional policy has become more and more concerned with the improvement of regional innovation capacities. The Lisbon Agenda transformed regional policy towards productivity and economic growth by fostering R\&D investments, in particular within the scope of the European Regional Development Fund: strict rules were introduced to regulate spending according to priorities including RDI. Studies about the impact of Cohesion Policy on innovation vary methodologically in many aspects and their results regarding the impacts of EU funding schemes on regional development and innovation are heterogeneous [22-26].

The Barca Report [27] — which underpinned the reform of the EU Cohesion Policy and highlighted its policy character alongside the redistribution of resources based on place 
and in a development policy context-was a turning point for the Smart Specialisation Strategy. The report reflected the challenges ahead for Cohesion Policy and admitted that a comprehensive reform is needed and a strong policy concept has to be applied. The report stated that place-based policy relies on local knowledge, a critical mass of interventions on commonly agreed priorities, and an increase of political and public attention. The concept of smart specialisation was described following years of work by the EU expert group of The Knowledge for Growth [28].

From an innovation policy viewpoint, it is crucial to combine the above two ideas: the expectation to take into account the actors of the innovation system, and the aspiration of cohesion policy, intended to set local strengths and opportunities into development focus. These two ideas are combined by the Smart Specialisation Strategy, which has taken a radically new approach regarding national and regional RDI policy and, from originally being a concept, it has become a policy [2]. Thus, S3 linked the spatial definition of innovation and entrepreneurship, with EU policies of regional aspects (including, among others, industrial policy, Cohesion Policy, and innovation policy), thereby practically becoming a regional development policy [29].

The theories on the role of specialisation of regional economic development contributed also to the development of the concept of smart specialisation strategies. Economic theories dealing with regional specialisation can be divided into three groups. The first group of concepts relies on economies of scale (both internal and external) as well as technology. Another group of theories emphasizes regional characteristics such as factor endowments and highlights the importance of external and internal markets [30]. Newer theories state that the theories based on the logic of comparative advantages do not describe the current situation properly; according to them, the microeconomic basis of development and corporate strategies have also become important sources of competitiveness in the globalised world economy. Michael Porter, in his comprehensive approach (competitive advantage theory), takes not only technology and economies of scale into account but also regional characteristics. Porter distinguishes different phases of competitive development (factor-driven, investment-driven, innovation-driven, and wealth-driven stages) according to which, then, sources of competitiveness can be defined [31]. The global value chains, organized mostly by large transnational corporations, are formed according to the specifics of production sites, not country-level characteristics [32]. This framework underlines the importance of regional factors in specialisation. Core-periphery specialisation theories focus on economic activities which concentrate around some pivotal points. Regional aspects of this scheme were first described by staple theory which describes the specialisation and relationships of Canadian regions. According to this, the developed regions were dependent on the accumulation of staples (agricultural products and raw materials) which were produced in periphery regions $[33,34]$. Another dimension of asymmetry exists in the knowledge-based economy wherein different characteristics and specialisations can be observed in the central regions and in the peripheries and semi-peripheries [35].

The policy consequences of the above-mentioned theories are the following: (1) The sources of competitiveness and the policy measures applied depend on factor endowments and the level of development of the regions - the core task of EDP is to define these priorities. (2) The level of integration into the global value chains and into the knowledge economy has to be taken into account; the more general approach of S3 in the new programming period reflects this challenge as S3, in the new programming period, covers not only RDI but also business development and digitisation. (3) The role of the local business sector is essential in specialisation, competitiveness and economic integrations; the substance of S3 and EDP (as later described) is about their involvement in policy making.

Smart Specialisation Strategy is a place-based policy tool focusing on the development of regions and specialisation directions. It became common in the European Union in the 2014-2020 development period [36]. At that time, the development of smart specialisation strategies was not just a recommendation: Regulation 1303/2013 of the European Parliament and of the Council states that a Member State can only receive funding from the 
Structural Funds to strengthen research, development and innovation, as well as for the development of information and communication technologies, if the given country has a smart specialisation strategy and the support is in line with that strategy's objectives. Consequently, the preparation of S3 documents was an ex ante condition to access funding from the Structural Funds.

S3 has been developed in all countries within a strict methodological framework defined by the EU. The Hungarian smart specialisation strategy for the period of 2014-2020 followed the principles and guidelines laid down by the EC [1,36], which highlight the following: the regional context and innovation potential; issues of participation and ownership; the formulation of a comprehensive vision for the region; the application of a coherent policy mix, roadmaps and action plans; and a system of monitoring and evaluation.

In the period of 2021-2027, S3 is an enabling condition for Member States. This means that the conditions for the strategy set by the EC must be met throughout the entire programming cycle $[37,38]$. Consequently, for the policy cycle to work properly, the EDP methodology must function not only during design but also during implementation [39]. Nevertheless, the methodological basis of S3 is the Entrepreneurial Discovery Process (EDP); this is a key element that follows through the planning of the 2014-2020 and 2021-2027 periods and, in the case of the latter period, of implementation as well.

\subsection{Entrepreneurial Discovery Process}

The application of the entrepreneurial discovery process (EDP) methodology is the cornerstone of the development of a smart specialisation strategy; th is an interactive, bottom-up process in which actors from different sectors (according to the quadruple helix model, this involves academia, industry, government and civil society) articulate what market niches they see and what they would need in order to set foot in them. They also need to identify potential strengths and opportunities for policy decision makers. The approach of the quadruple helix model is very useful for those involved in the smart specialisation strategy, despite its difficulties, as it involves not only the producers of knowledge but also includes the users of the created knowledge in the process [20].

Businesses in the local economy have an important role to play in technological development and exploration of market opportunities [1,29]. The system of goals and instruments developed taking into account the needs and challenges of the local economy determines the potential strengths, competitive advantages and possible breakout points for the structural transformation of the economy. An important message is that it should not be based solely on university or research institute bases, even if those are world-class, but should also build on the strengths that local businesses need, since the main goal of S3 is to strengthen local business/industry expertise by working together with all local knowledge bases [40].

When developing S3, it is necessary to consider how enterprises can create commercially usable products and innovations, especially with regard to future market opportunities. In the application of the EDP methodology, ongoing consultation plays a key role in ensuring that stakeholders identify with jointly developed objectives and build cooperation with each other in a conscious, bottom-up way. Based on these principles, the applied methodology of the EDP is different in each EU country [41,42].

Although the involvement of innovation system actors in the prioritisation process is a theoretically easy-to-meet expectation, its practice is an actual learning process for the countries that apply it.

One of the novelties of our paper is that we analysed in detail the methods and changes in the prioritisation used in the application of the EDP methodology in Hungary. Although there are papers analysing S3 planning $[4,43]$ as well as implementation and EDP of specific countries, this is the first paper to compare different EDPs in a given country. Another dimension of novelty is that the analyses of the planning of S3 in the programming period of 2021-2027 is a missing part of the literature as other countries' experiences are not yet available. 
We set up three hypotheses: (1) there are significant differences between the two periods in terms of methodologies used in EDP and in prioritisation, especially regarding the involvement of stakeholders; (2) the experiences of the first period have an impact on the planning of the strategy of 2021-2027; (3) the different methodology of EDP and prioritisation led to a more coherent list of priorities.

\section{Materials and Methods}

Based on Hungarian strategies and other policy documents, international and Hungarian literature, this paper analyses the involvement of relevant actors in strategic planning and prioritising. As EDP methodology was applied in the planning of the S3 for the period of 2014-2020, we concentrate on this and the following (2021-2027) period.

The key sources of the research were the two accepted strategies (for 2014-2020 and 2021-2027, respectively), which included in-depth descriptions of the used methods of EDP and prioritisation. As the EC supervised the methodology of the planning of these strategies, and the Hungarian government had to demonstrate the way of fulfilling the criteria set up by the EC, the policy documents covered the above-mentioned topics very precisely. As the structures of the documents are similar and they used the same terminology, the use of content analysis methods was not required. Another key source of the analyses was the Hungarian S3 monitoring report of the programming period 2014-2020 which was based on project level data and has detailed data for drawing conclusions on the implementation of the strategy [44].

\subsection{Hungarian Strategic Framework before 2014}

In the transition period in the 1990s, several policy-level and organizational changes affected the innovation landscape of Hungary; formal strategies were not published. In 1998, the Hungarian Technology Foresight Programme was launched, outlining visions and programmes for the future [45]. After this, the Széchenyi Plan, in 2000, was the first coherent attempt towards an innovation strategy with a long-term view, underlying the importance of RDI. The document, called Science and Technology Policy 2000, was also published as part of the Széchenyi Plan, with analyses of challenges and descriptions of major programmes [46].

When Hungary joined the European Union in 2004, innovation policy gained regional aspects. In line with the European Union's renewed Lisbon strategy and the European Research Area, Hungary adopted the axioms that strengthening the competitiveness of Europe as a whole is not possible without supporting the competitiveness and innovation capacity of regions. Hungary also gained access to EU Structural and Cohesion Funds, which emphasised the importance of RDI and regional viewpoints at the same time. From 2004, the framework for the regional aspects of innovation policy consisted of National Development Plans (which prepared for the reception of EU Structural Funds), National Development and Territorial Development Concepts (according to law XXI, 1996) and strategic documents specifically on RDI. The first, from the latter group, with regional dimensions was the concept paper Establishment of Regional Innovation System. Based on this, the establishment of regional innovation agencies (in 2005) was promoted to encourage and facilitate cooperation between innovation actors in each region [47].

Although the organizational framework of innovation policy (policy coordination body and the implementing agency) had changed several times up to 2015 (in which year the National Research, Development and Innovation Office was established), the models of innovation policy showed relative stability. A cluster analysis of country patterns of the innovation policy mix between 2003-2012 showed that Hungary followed an innovation policy focusing on business $R \& D$ and innovation coupled with support for competitive R\&D [48].

The country-level strategic framework was laid down in Midterm Science, Technology and Innovation Strategy 2007-2013 and later in the Investment into the Future-National 
Research and Development and Innovation Strategy 2013-2020. In addition to these, between 2005 and 2014, regional innovation strategies were planned on NUTS2 level.

Although it is not unprecedented that a strategy applies a questionnaire to confirm its statements, e.g., the Regional Innovation Strategy in the South Transdanubian Region [49], none have applied any systematic bottom-up approaches or any methods similar to EDP. In spite of the existence of these strategies, Hungary's national innovation system remained fragmented in smaller subsystems and the national level no longer added to the synergy across these regional innovation systems [50]. Another, systematic policy approach was needed which was able to take into account the country level, mostly horizontal goals and the regional strengths and possibilities to utilize the synergies between national and regional ecosystems.

\subsection{EDP Methodology for the Period 2014-2020}

In the planning of the first Hungarian smart specialisation strategy for the period of 2014-2020, the EDP was carried out in accordance with the methodology defined by the EC. The basis of the process was that of county workshops: in the autumn of 2014, S3 workshops were held in all Hungarian counties (on NUTS3 level) with the involvement of local RDI ecosystem actors, in two different rounds. The National Innovation Office was responsible for organizing the EDP and developing its methodology.

During the first round of county events, the participants first got acquainted with the relevant county RDI statistics. For this purpose, the National Innovation Office prepared documents containing county profiles (economic, social, R\&D, etc., indicators). Based on this, the participants formulated regional priorities and specialisation directions. In the process of creating the range of participants in the workshops, the organizers made a special effort to ensure that the participants accurately represent the economic structure of the counties (both in terms of business branches and sectors), and human competencies and skills. In order to determine the county specialisation directions, the workshops worked with the following methodology.

In the workshops, groups of 8-10 people (in a few cases, less) were seated according to a pre-determined (registration-based) composition. All four branches of the quadruple helix were represented in the composition of each group. The introductory lectures of the workshops described the general economic and RDI statistical characteristics of the county, as well as the methodology of the two-round group work. A maximum of four priorities had to be identified by consensus within the groups according to the conditions described.

The discussions of the participants in the meeting were moderated by the county facilitator, who, with the participation of the members of the S3 working group present, drew attention to the focus and the time factor, but did not make any suggestions. In the final part of the workshop, the priorities proposed by the groups were projected after summarizing the content. During the second exercise, each group rethought and clarified its own priorities based on the summarized and projected material. If in the first round one of their proposals was too general, it was possible to further specify their specialisation. Following the two rounds of group work, the facilitator presented the re-summarized county priority proposals, while also providing opportunities for comments and remarks.

The methodology used in the workshops reduced the likelihood that local development policy efforts would be based on the development patterns of other counties. Since imitation might lead to the continuation of fixed patterns, and the EDP methodology aims to be a tool for regions to tailor their economic development objectives to their own capabilities and opportunities, involving local decision makers by identifying relevant priorities and RDI needs, any such continuation is undesirable.

In addition to the prioritisation suggestions of the county workshops, S3 designers collected suggestions in an online, publicly accessible questionnaire. In the questionnaire, the prioritisation suggestions could be given by the respondents by answering openended questions. During the processing, the specific proposals developed at the county workshops and collected in the online questionnaire were categorized and grouped. The 
processing took place in parallel, based on the same methodology and categories, but separately according to the origin of the data (workshop/questionnaire). An examination of the statistical substantiation of the summarized county (workshop and questionnaire) proposals also had to be carried out in order to see whether the proposed specific priority was a statistically verifiable strength in the given county.

In the second phase of the county workshops, the county working groups could get acquainted with, comment on and supplement the draft strategy prepared based on the previous phase, and further refine the entire document. Commenting was also possible via an online questionnaire with both open and closed questions, as well as in the form of informal comments submitted in e-mail.

As a result of the EDP methodology presented below (see Figure 1), sectors, technologies and research directions relevant to the strategy were identified. A total of three national specialisations, six sectoral and two horizontal national priorities were born. National specialisations were systems science, smart production and sustainable society. Sectoral national priorities were healthy society and well-being, advanced technologies in the vehicle and other machine industries, clean and renewable energies, sustainable environment, healthy and local food, and agricultural innovation. Horizontal priorities were ICT (infocommunication technologies) \& services; inclusive and sustainable society, and viable environment. In addition, in defining county specialisations, participants in the EDP methodological process decided to use more advanced technologies and to renew some traditionally present industries that could not be directly integrated into national priorities, but the potential at local level sectoral interoperability of technologies justified their emphasis; the S3 document also set out these smart technologies at the county level.

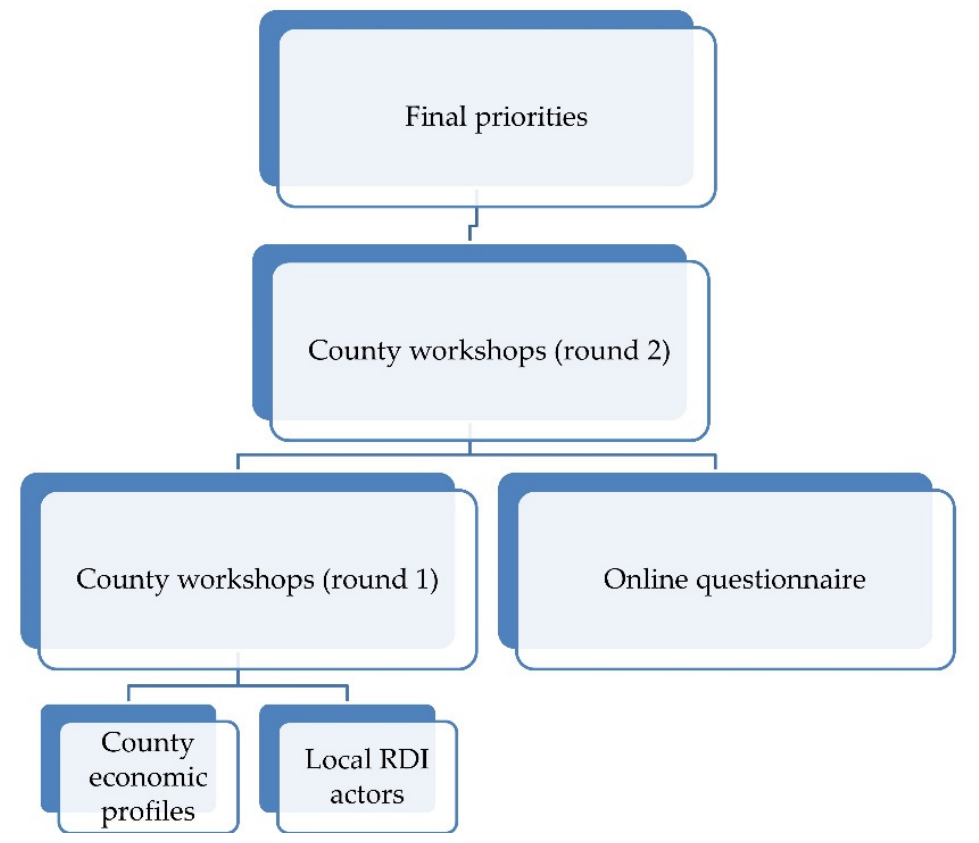

Figure 1. Prioritisation in the planning of S3 2014-2020.

\section{Results}

During the planning and implementation of Smart Specialisation Strategies in the programming period of 2014-2020, several questions were raised regarding the framework and operation. In line with the concept of this paper, we concentrate on the lessons learned related to EDP and prioritisation during the first cycle of S3 planning and implementation.

\subsection{Experiences and Concerns-International Overview}

A report of the Joint Research Centre summarized the experiences of EDP in the period of 2014-2020. Based on survey data and case studies, it highlighted "that there is 
still no universal understanding of what the continuous entrepreneurial discovery process should look like in practice" [43] (p. 12). Regarding the means of EDP, focus groups, working groups, workshops and forums used to be the most important measures (75\% of countries used them), surveys, consultations and information gathering were also among the most popular means. Online platforms (sharing information and documents, promoting dialogue and construction of arguments) were used by less than half of the countries. They are followed by brochures, pamphlets, magazines, facts, numbers and figures to inform the general public and only $25 \%$ used institutional bodies for decision-making processes to produce formal co-decisions between public actors and stakeholders.

The report stated that institutional and cultural factors, and historical trajectories of innovation policies have a major impact on the methodology of EDPs. Due to the large number of countries and regions applying EDP and the heterogeneity of their practices, we would like to briefly describe the case of other Visegrád Four (V4) countries-these countries are economically, culturally and socially similar to Hungary.

In the Czech Republic, the draft of the main conclusions was prepared before the EDP, and the specialisations were refined in the regional annexes of the national strategy; discussions with stakeholders were organized on regional levels. In the next phase, the document underwent several rounds of discussions: it was discussed three times and approved by the National RIS3 Coordination Council and it was also the subject of a round-table meeting with representatives of leading companies and research institutions concerning four innovative platforms [51].

In Slovakia, where the degree of centralization in the field of innovation is higher, the organization of EDP faced deficiencies [52]. Although the planning of S3 was based on the quadruple helix model, the level of involvement and cooperation remained weak. Over 120 experts (Slovak Academy of Sciences, universities, civil society associations and industry) consulted the document. The priorities were defined by the government and legitimised by stakeholders afterwards in the form of EDP [53].

The Polish case is different as, with the help of the World Bank, the country adopted a special type of focus group, called Smart Labs. The process started with desktop research and with semi-structured interviews to identify potential economic areas, champions and relevant stakeholders. In the next phase, Smart Labs defined the potential of each business area and prepared a midterm strategy. The Smart Labs had 15-20 participants comprised of eight to ten entrepreneurs, three universities/research institutions, three business support institutions, and representatives of the regional and national government. They prepared a report with proposals for steps that must be taken and published it online to share it with other stakeholders [54].

Besides the heterogeneity of EDP and the prioritisation implemented in European countries, more general questions can be raised about the essence of S3. It is not obvious whether smart specialisation is about specialisation or smart diversification (where competitive advantages are defined and regions differentiate themselves from others) [55]. It is possible that local actors misunderstood the concept. The plurality of the understanding of this term and the upset over "specialisation" and "diversification" led to sub-optimal policy outcomes. In the response, it was acknowledged that the term 'specialisation' might not be appropriate as there is a distinction between the concepts of "specialisation" (which means concentration of resources and choice of priorities) and "transformation" (described by diversification, transition, and modernization) [56].

Another point made by critics is that EDP can be a useful method to identify sectoral comparative advantages in regions but, due to the existence of several factors, S3 "consist of wishful thinking that entrepreneurial discovery process can lead regions to lock out of negative path dependence" [55] (p. 9). These potential challenges are, inter alia: vested interest groups need to be incorporated in the process; the EDP can hardly build on regions with low levels of entrepreneurial activity; local stakeholders may have rentseeking behaviour, and local myopia (local political stakeholders try to strengthen existing structures, and lack of knowledge about the international competitive position of local 
activities). It is also questionable whether the required structural changes can be achieved by incremental steps. In his response, Foray [56] admitted that vested interests exist but there is a belief that the process can be more transparent and some choices can be delegated to experts. The new concept of EDP is not about prioritisation, as it will only take place after that, while it concentrates on transformative activities. As smart specialisation is a transformative process, there is the possibility for breakthroughs.

\subsection{Hungarian Lessons Learned from the Period 2014-2020}

The Hungarian S3 monitoring report of the programming period 2014-2020 [44], and other experiences of the development period, highlighted in several respects that the EDP (mainly the setting of priorities) should be operated in a methodologically different way.

An important lesson from the above-mentioned monitoring report was that in a significant number of counties the distribution of RDI grants among priorities often does not reflect the directions set by the counties in the planning of S3; there were county specialisation targets for which no applications were received and, in other cases, there were only a minimal number of applicants. Moreover, the list of priorities selected was too broad, so the strategy did not set out real, definite specialisation directions. The system of county, national and horizontal priorities was difficult to review, as, in addition to county specialisations, smart technologies were also defined on a county level. Additionally, the strategy also set horizontal and sectoral priorities on a national level.

The policy lesson drawn from this was that prioritisation should be better managed throughout the application of the EDP methodology and that stronger selection and control is needed. Prioritisation was also shown to represent, to some extent, a return to the beginnings of innovation policy, as top-down operation appears to be one of the key elements of success. This can make the distribution of RDI grants between priorities to be better targeted.

Based on the monitoring report, it can be stated that there indeed are differences in emphasis between the strengths of each county, but there are no really significant differences in terms of challenges and main goals that would justify setting completely separate priorities for each county. Furthermore, there are too many counties for independent smart specialisation strategy development or priorities; this also served as an important lesson for the planning of the 2021-2027 strategy. Therefore, Hungary planned only one strategy consisting of national aims instead of developing NUTS3-level strategies and defining county-level priorities.

Although the EDP methodology was in all respects in line with the guiding principles laid down by the European Commission, it did not achieve the real goal of S3: it failed to steer developments towards real specialisation. It should be noted here that the situation is not Hungary-specific. A study covering 7 countries (Italy, Poland, Portugal, Hungary, the Czech Republic, Lithuania, and Slovenia) identified the following similar problems: with the priorities being too broad, covering most of the economy, implementation was not significantly different from that of traditional (sector-independent) industrial policy. Furthermore, some calls were not linked to priorities, and certain interventions tried to circumvent S3 intervention logic [57]. Other examples showed similar problems in Wales and Estonia: in both countries, S3 was planned and implemented by the central government in a top-down logic. In Wales, the strong role of the central government distorted EDP, the strategy was integrated into the pre-existing cluster-based policy and the priority areas remained the same. In Estonia, the priority areas were changed to a lesser extent and had little connection to the structure of the country's economy. In addition, the involvement of private actors was weak and the inclusion of local municipalities remained limited [58].

Due to these experiences, the 2021-2027 planning in Hungary already required prioritisation differing from sectoral logic. Priorities were not reviewed or modified through the EDP methodology during implementation. Hungary did not conduct an interim evaluation that would have involved RDI actors in the feedback process to any extent, even though the EDP methodology would have been suitable for this. International examples show that 
a few European regions did carry out an interim evaluation of S3. As a result, Lithuania, for example, eliminated seven previously selected priority areas, while the Polish region of Silesia identified two new areas of specialisation [59].

Partly due to lack of guidelines for the central EU-level EDP methodology, the Hungarian S3 and its priorities have not changed since 2014; this affected its relevance negatively. However, besides the aforementioned problems, modifications would have been necessary because, in the way things went, the changed sectoral and technological conditions of the period of 2014-2020 were not reflected in the strategy. The lack of an EDP methodology in the implementation resulted in rigid priorities and specialisations wherein real needs are only reflected to a lesser extent. This is not a unique phenomenon as Portugal faced a similar problem: the EDP process failed during the implementation and the priorities were not modified. Platforms and thematic discussion groups were established in the regions quite late and their main motivation were not policy-related "but to undertake a 'tick the box' exercise" required by the smart specialisation methodology [60].

S3 2021-2027 notes that the adoption of S3 was not sufficiently supported by policy communication. Although the 2014-2020 period resulted in a wide range of stakeholders becoming aware of $\mathrm{S} 3$, the real role and expected impact of $\mathrm{S} 3$ has not become sufficiently known among actors.

This is partly due to the fact that the actors of the RDI system were involved in the planning of S3 through the EDP methodology, but no longer in the implementation. In particular, communication programs were not connected to S3 after the completion of the planning of the strategy, and the EDP methodology was practically missing during the implementation period.

\section{Discussion}

\subsection{A New Approach of EDP in the Planning of S3 for 2021-2027}

In 2021-2027, smart specialisation strategies aim to contribute to the implementation of the Cohesion Policy Objective 1 "a more competitive and smarter Europe by promoting innovative and smart economic transformation and regional ICT connectivity" [61]. Therefore, as an umbrella strategy, S3 now covers not only RDI but also business development and digitization - this means a change compared to the implementation phase of the previous S3, since the areas of digitization and business development also took part in the process, and the EDP methodology was expanded too, involving new target groups into the process.

The application of the EDP methodology was essentially discontinued after the adoption of the 2014-2020 S3. Therefore, the revitalization of relations with RDI actors was of paramount importance, one wherein the first step was the organization of the National Innovation Forum (NIF). The NIF, held in March 2019, in 25 locations and involving more than 2500 stakeholders, was organized by the Ministry of Innovation and Technology and the NRDI Office, with the participation of the Hungarian Chamber of Commerce and Industry as a key professional partner. The national consultation involved local and regional businesses, knowledge centres and professional organizations. The aim of the series of events involving all Hungarian counties, which itself was part of a wide-ranging collaboration, was to establish Hungary's reorganizing innovation ecosystem and to assess the proposals and needs arising in connection with the renewable RDI system, the new RDI Strategy and calls.

The events were also accompanied by an online consultation. In addition to the main objectives of the National RDI Strategy 2021-2030, the actors of the RDI system were able to express their opinions on the planned calls for proposals. Although the NIF took place applying a horizontal focus, the series of events can be considered part of the EDP methodology, as it established the target system of the RDI Strategy, which is closely related to S3.

From an RDI point of view, the long-term basis of the EDP methodology related to strategic planning and implementation is the establishment of Regional Innovation 
Platforms (RIPs). RIPs were established at bases in university centres and their aim is to operate regional organizations across the country, building on university knowledge bases, which at the same time provide an opportunity for domestic actors to learn directly about innovation policies, and to establish and strengthen collaborations between members of the local innovation ecosystem in order to create a new professional background. RIPs are entities within the organization of universities, without an independent staff-the higher education institutions serve as background capacities to operate the platforms.

It is crucial for the future performance and competitiveness of the Hungarian innovation ecosystem that the relations of the actors-policy makers, higher education institutions and research institutes, enterprises and professional organizations-are strengthened at the local level, in accordance with S3 directives. Regional Innovation Platforms promote a new approach to information flow, knowledge transfer, cooperation and professional networking.

Between November 2019 and February 2020, the plenary presentations of the President and Vice-Presidents of the NRDI Office on the Planning of the Smart Specialisation Strategy took place at the until then stages of the national series of events concerning RIPs (Miskolc, Debrecen, Győr, Szeged, Pécs, Budapest, Veszprém and Gödöllő) in order to acquaint the audiences with its principles and goals. Next, during a professional round table discussion, the local actors shared their experiences regarding the implementation of the previous strategy and the results of the regional cooperation and jointly analysed the strengths, opportunities and areas to be developed in the region. At the stations of the program series, the participants had the opportunity to consult with the members of the S3 working group of the NRDI Office, and at the S3 stand of the Office, the participants were also able to fill in the online questionnaire on S3 priorities.

The S3 questionnaire constituted one of the most important elements of the EDP methodology. The questionnaire was available on the website of the NRDI Office between 12 November 2019 and 12 March 2020. In order to reach the widest possible range of RDI actors, the Office also requested the support of professional organizations, i.e., local chambers of commerce and industry, regional innovation platforms, universities and the largest municipalities, in filling out the online questionnaire and sending it to their member organizations. Applicants who received support from the NRDI Fund received the questionnaire in the form of a presidential letter, and the call also appeared in the NRDI Office's newsletter and on its website. Altogether, 2030 respondents started completing the questionnaire and, in the end, 829 complete questionnaires were submitted.

The questionnaire was based on the long list of priorities. This identified socioeconomic-technological areas of potential breakthroughs and challenges that are important for Hungary, grounded in global technological, social and economic megatrends, relevant domestic policy strategies and their priorities (as well as the specialisation directions of EU member states). This approach is in harmony with the concept of innovation policy 3.0 which pays increasing attention to challenges such as climate change or ageing societies or the mission-oriented innovation policy [62]. It is important to note the three frames of science, technology and innovation policy: innovation policy 1.0 refers to the post-war science period when the support schemes were institutionalized. Innovation policy 2.0 describes the systems of innovation models since the 1980s, concentrating on cooperation between actors. The current socio-ecological innovation policy 3.0 deals with grand challenges and sustainable transformation [63].

In line with that, Foray defined smart specialisation strategies also as a kind of missionoriented policy, as it is non-neutral and defines new types of missions. The new method of EDP reflects not only the problems defined in the Hungarian planning and implementation but some of the above-mentioned arguments of Hassink-Gong [55] were also reflected. The long list tried to avoid local myopia as possibilities of global megatrends and Hungarian strategic priorities were presented. The online questionnaire and the wide geographical basis of RIPs allowed for the involvement of as many local stakeholders from the less active regions as possible. The process of defining the short list of priorities is illustrated in Figure 2. 


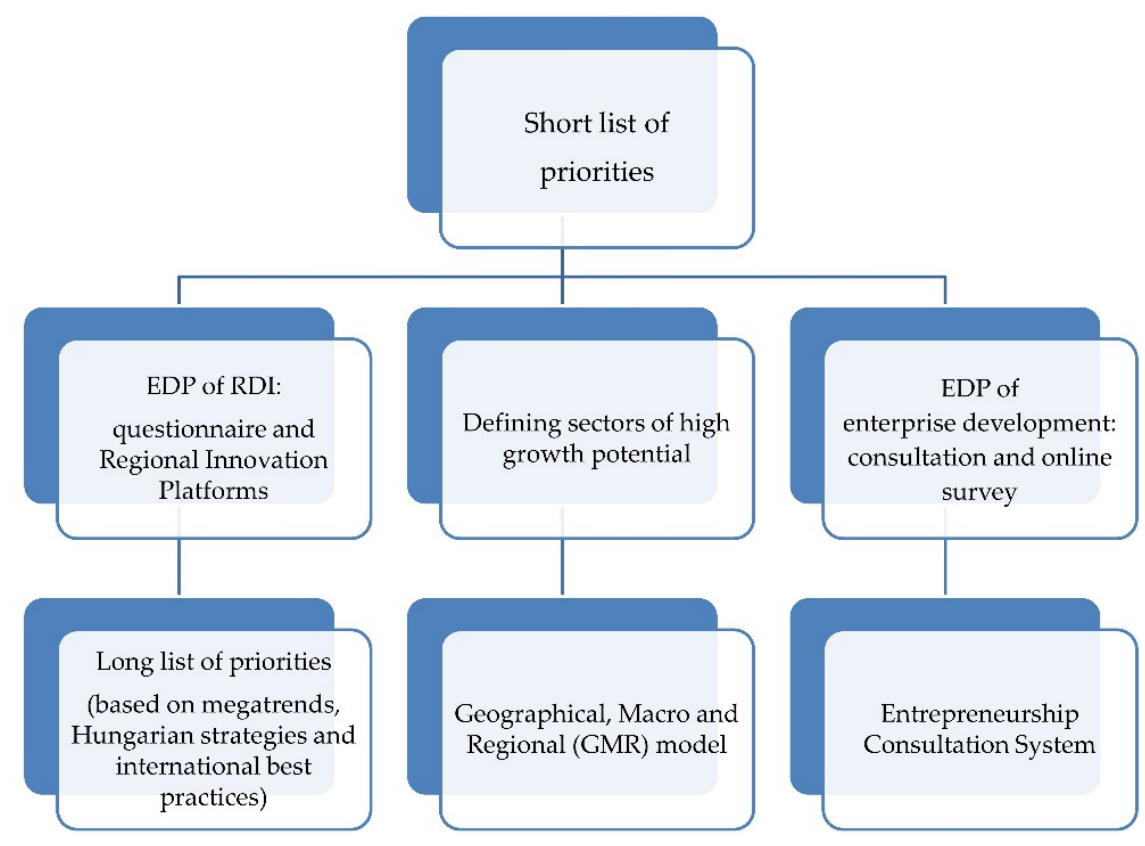

Figure 2. First phase of prioritisation in the planning of S3 2021-2027.

The methodological basis of the EDP from a business development perspective was the Entrepreneurship Consultation System. This is a system that supports the implementation of the Strategy for strengthening Hungarian micro, small and medium-sized enterprises in 2019-2030, which regularly probes the opportunities, difficulties, ideas, needs and opinions of enterprises, based on consultative elements and queries. The nationwide consultation process, led by the Ministry for Innovation and Technology, was carried out in cooperation with business organizations and the Hungarian Chamber of Commerce and Industry. The consultation was accompanied by a representative business survey in the form of an online questionnaire complemented by an additional telephone inquiry. The request will be repeated annually as planned and will be related to the national consultation.

The topics of the consultation are determined by current developments in the economy and policy. Accordingly, the topics of the 2020 consultation series were organized around the EU planning for 2021-2027 and the effects of the pandemic on businesses; its results also contributed to the preparation of S3.

The priorities defined on the basis of the elements of the EDP and the GMR (Geographical, Macro and Regional) model developed by the Regional Centre for Innovation and Entrepreneurship (RIERC) of the University of Pécs (in line with the lessons of the 2014-2020 S3 analysed above) were validated by the main RDI actors in the form of an online questionnaire in November 2020. When applying the EDP methodology, there are wide possibilities for exploiting online opportunities [64]. The 10 priorities defined during the first phase following the application of the EDP methodology were sent by the NRDI Office to a total of 106 organisations representing all the major players in the quadruple helix model.

Thus, the questionnaire prepared for the professional validation of the priorities was also received by the horizontal organizations in the fields of digitization and enterprise development, and all members of the Hungarian Business Development Council participated in the professional validation. Respondents had the opportunity to comment on the priorities developed in the previous stage of the EDP, and also on their objectives and content. The resulting modified list of priorities was also commented on by the relevant public administration actors in the framework of administrative validation-this is how the final priorities of the S3 for 2021-2027 were formed. For the second phase of prioritisation see Figure 3. 


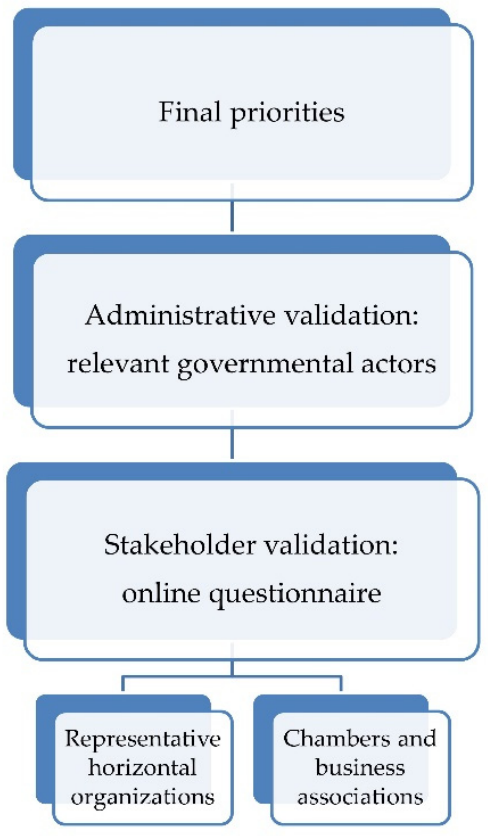

Figure 3. Second phase of prioritisation in the planning of S3 2021-2027: validation.

The final national economic priorities for S3 2021-2027 are cutting-edge technologies, health, digitalisation of the economy, Energy, climate, services, resource-efficient economy, agriculture, food industry, and creative industries. Horizontal priorities are training, education, public sector and university innovation.

\subsection{EDP Methodology in the Implementation of the 2021-2027 S3}

In order to achieve the effective implementation of $S 3$, the aim is to create a stable institutional system that is transparent to all actors of the quadruple helix: the smart specialisation process does not end with the government's adoption of S3 as a strategic document, and the implementation of the strategy should focus on the EDP methodology throughout the whole implementation cycle.

Regional Innovation Platforms form the basis for the implementation of the EDP for the period of 2021-2027. The RIP initiative strengthens the links between actors at the local level, i.e., higher education institutions, research institutes, businesses, professional organisations, policymakers, and facilitates the flow of information, knowledge transfer and cooperation in the field of research and innovation, validating the logic of quadruple helix. Higher education, as an actor where human, research and innovation resources are available to all businesses, is considered a key institution of the innovation system.

The situation is similar with regard to infrastructures supporting research and innovation. The supporting role of higher education strengthens the logic of open innovation [65] in domestic enterprises. Ultimately, university-based platforms will strengthen cooperation between actors, in addition to increasing the competitiveness of SMEs. During the implementation of the strategy, the RIPs represent the regional level of cooperation and support the sharing of data, information, experiences, and the dissemination of results.

The stakeholder network consists of Regional Innovation Platforms organized on a territorial basis. These platforms and expert groups participate in the S3 working groups and ensure the continuous application of the EDP methodology during implementation.

RIPs are responsible for ensuring the local embedding of S3 goals and objectives and are regularly consulting with stakeholders as part of the EDP methodology. They contribute to the management of S3 by providing information for regular monitoring and evaluation activities regarding certain actors of the S3 institution system, as a result of which the implementation of $\mathrm{S} 3$ can be reviewed, priorities can be updated, and interventions can be refined. 
The evaluation and monitoring system of S3, the local actors involved in the implementation, the changed economic situation due to the pandemic, as well as the experience of the implementation of the operational programs of the 2014-2020 EU programming cycle require continuous review and continuous development as well as regular monitoring and feedback. Reducing the distance between policy thinkers and doers is an important task in applying the EDP methodology [3], so in its further stages, during the operation of the RIPs, great emphasis should be placed not only on the collection of information by the government, but also on dialogue.

This is also particularly important for the concept of Responsible Research and Innovation (RRI), which is based on a transparent and interactive process in which social actors and innovators take mutual responsibility for the innovation process and the ethical acceptability, sustainability, and social desirability of its results in order to integrate scientific and technological development into society [66,67].

We concluded that our first hypothesis is true: we found significant differences between the two periods in terms of methodologies used in EDP and in prioritisation, especially regarding the involvement of stakeholders; the preparation of the long list, the use of the GMR model and the validation process are the most significant new elements compared to the previous period. Regarding the second hypothesis, we could see that the experiences of the previous period had a major impact on the planning of the 2021-2027 strategy. The list of priorities was too broad and complex, therefore the new EDP started with a long list, a macroeconomic model was applied and the validation phase was also added. As a weakness of the implementation, the lack of continuous EDP, was obvious, the new strategy includes plans on continuous EDP (based on Regional Innovation Platforms) and a feasible monitoring and evaluation framework. We can, therefore, accept the second hypothesis too.

According to the third hypothesis, the different methodology of EDP and prioritisation led to a more coherent list of priorities. Instead of the complex system of county, national and horizontal priorities, county level smart technologies, horizontal and sectoral priorities in 2014-2020, Hungary set up a system of national and two horizontal priorities for 2021-2027. Therefore, the third hypothesis can be also verified.

\section{Conclusions}

The EDP methodology, like all new initiatives, underwent a kind of learning process during the period 2014-2020. The very idea that a smart specialisation strategy should be established based on the widest possible involvement of the actors of the innovation system placed a strong emphasis on the so-called bottom-up logic approach, however, at the same time, innovation policy cannot cope without top-down logic. This was well evidenced by the fact that the distribution of RDI support between priorities in the period 2014-2020 only partly reflected the directions set by the counties during the planning of S3, i.e., the strengths perceived by the actors did not coincide with the real strengths in the counties later.

One reason for this was that the bottom-up approach necessarily resulted in a list of priorities that was too broad, with the result that the strategy did not (or, rather, could not) define real, definite areas of specialisation. The fact that the sectoral approach was not able to adequately reflect the trends and global (economic, social, and technological) challenges in the field of RDI, meant a further problem.

It should be noted that the adoption of the $\mathrm{S} 3$ was not sufficiently supported by policy communication either. At the same time, it is certainly a good result that in the period of 2014-2020 a wide range of stakeholders became aware of the S3, however, the application of the EDP methodology, as it was a one-time design event, could not become an integral part of the S3. However, with all things considered, the policy did not intentionally pursue the EDP methodology, but rather lacked the understanding that $\mathrm{S} 3$ is not set in stone but can be changed. 
When planning the period of 2021-2027, taking into account these lessons, it has become clear that during the EDP, prioritisation needs to be better managed, and stronger selection and control are needed. This way, the EDP methodology was able to become significantly more efficient, the actors were also able to extend their view beyond the sectoral focus and, last but not least, to reflect on its relevance by understanding the main directions of innovation policy in advance. It is expected that the distribution of RDI grants between priorities can be made more targeted in such a way that they contribute to strengths, which is ultimately the goal of the S3.

An important result of the previous S3, however, was that the EDP methodology as a concept did not need to be re-introduced to the actors of the domestic innovation system-except that, naturally, the new elements had to be introduced and implemented. The success of the previous EDP methodology, despite its flaws, is well indicated by the fact that interest was significant regarding the 2021-2027 EDP, and thus, regarding the S3 as well.

The organization of the National Innovation Forum (NIF) was the first step in contacting the actors, however, the establishment of Regional Innovation Platforms (RIPs), from an RDI perspective, forms the long-term basis of the EDP methodology that is also related to strategic planning and implementation. The platforms promote the flow of information and knowledge transfer, as well as cooperation and professional networking with a new approach, therefore their role in the operation of S3 is of utmost importance.

Thus, according to our thesis, the choice of the priorities of the smart specialisation strategy is a multifactorial decision problem, so it cannot be based solely on the onetime opinion of the regional stakeholders of the RDI system and its direct channelling into the priorities. The task of the policy is to select the areas to be developed based on Hungary's strategic goals and global challenges, involving as wide a range of stakeholders as possible and, at the same time, to incorporate appropriate control mechanisms to ensure the validation of the priorities set out by the innovation system.

As general recommendations for policy-making: (1) prioritisation cannot be based solely on the one-time opinion of the regional stakeholders of the RDI system, EDP should be a continuous process; (2) direct channelling of the opinions of stakeholders into the priorities leads to a broader scope, a purely bottom-up process could result in suboptimal sets of priorities (3) there is a need for a preparatory phase and tools that manage EDP prioritisation in a supportive way and which are able to validate results; and (4) innovation policy has to handle the problems of vested interest groups and low level of entrepreneurial activity-communication, and well-defined methodologies (such as validation) is needed.

Beyond the institutional framework, an important element in communication (the first element of which was the coordination of priority directions) is the S3 questionnaire in the EDP methodology. This identifies possible socio-economic-technological areas that represent important breakthroughs and challenges for Hungary, based on global technological, social and economic megatrends, relevant domestic policy strategies and their priorities.

The methodologically important lessons of the two completed S3 EDPs are that the continuous operation of the EDP can only bring about a breakthrough in competitiveness and innovation by continuously monitoring RDI trends, and by treating the strategy as a flexible, organic document. The most important limitation of our study was that the smart specialisation strategies for the new period are not published by other countries for the period of 2021-2027 and evaluations of policy means (such as EDP during implementation or redefining priorities) were also missing. Further research is needed to compare the Hungarian renewal of EDP with methods of other countries for the current programming period and to study the methods of implementation of EDP in other countries during 2021-2027. 
Author Contributions: Conceptualization, Z.B., Á.M. and I.S.; methodology, Á.M. and I.S.; formal analysis, Á.M.; investigation, Á.M.; resources, Z.B. and I.S.; writing—original draft preparation, Á.M.; writing-review and editing, I.S.; supervision, Z.B. and I.S. All authors have read and agreed to the published version of the manuscript.

Funding: We acknowledge the financial support of Széchenyi 2020 under the EFOP-3.6.1-16-201600015.

Institutional Review Board Statement: Not applicable.

Informed Consent Statement: Not applicable.

Data Availability Statement: Not applicable.

Conflicts of Interest: The authors declare no conflict of interest.

\section{References}

1. Foray, D.; Goddard, J.; Beldarrain, X.G.; Landabaso, M.; McCann, P.; Morgan, K.; Nauwelaers, C.; Ortega-Argilés, R. Guide on Research and Innovation Strategies for Smart Specialisation (RIS3 Guide)—Smart Specialisation Platform; Publications Office of the European Union: Luxembourg, 2012. Available online: https://ec.europa.eu/regional_policy/sources/docgener/presenta/ smart_specialisation/smart_ris3_2012.pdf (accessed on 15 January 2021).

2. Foray, D. From smart specialisation to smart specialisation policy. Eur. J. Innov. Manag. 2014, 17, 492-507. [CrossRef]

3. Santini, C.; Marinelli, E.; Boden, M.; Cavicchi, A.; Haegeman, K. Reducing the distance between thinkers and doers in the entrepreneurial discovery process: An exploratory study. J. Bus. Res. 2016, 69, 1840-1844. [CrossRef]

4. Kogut-Jaworska, M.; Ociepa-Kicińska, E. Smart Specialisation as a Strategy for Implementing the Regional Innovation Development Policy—Poland Case Study. Sustainability 2020, 12, 7986. [CrossRef]

5. Brooks, H. The Military Innovation System and the Qualitative Arms Race I Belfer Center for Science and International Affairs. Daedulus 1975, 104, 75-94.

6. Bajmócy, Z.; Inzelt, A. Az innováció építőkövei. In Innovációs Rendszerek: Szereplők, Kapcsolatok És Intézmények; Bajmóczy, Z., Inzelt, A., Eds.; JATEPress: Szeged, Hungary, 2013, ISBN 978-963-315-158-7.

7. Godin, B. National Innovation System: The System Approach in Historical Perspective. Sci. Technol. Hum. Values 2009, 34, 476-501. [CrossRef]

8. OECD. National Innovation Systems; OECD: Organization for Economic Co-Operation and Development: Paris, France, 2007. Available online: https:/ /www.oecd.org/science/inno/2101733.pdf (accessed on 15 January 2021).

9. Lundvall, B. National Innovation Systems-Analytical Concept and Development Tool. Ind. Innov. 2007, 14, 95-119. [CrossRef]

10. Lundvall, B.-A. National Systems of Innovation: Towards a Theory of Innovation and Interactive Learning; Pinter: London, UK, 1992, ISBN 1-85567-063-1.

11. Freeman, C. The "National System of Innovation" in Historical Perspective. Camb. J. Econ. 1995, 19, 5-24.

12. Malerba, F. Sectoral systems of innovation and production. Res. Policy 2002, 31, 247-264. [CrossRef]

13. Carlsson, B.; Stankiewicz, R. On the nature, function and composition of technological systems. J. Evol. Econ. 1991, 1, 93-118. [CrossRef]

14. Cooke, P. Regional innovation systems: Competitive regulation in the new Europe. Geoforum 1992, 23, 365-382. [CrossRef]

15. Varga, A. Place-based, Spatially Blind, or Both? Challenges in Estimating the Impacts of Modern Development Policies. Int. Reg. Sci. Rev. 2017, 40, 12-37. [CrossRef]

16. Varga, A.; Szabó, N.; Sebestyén, T. Economic impact modelling of smart specialization policy: Which industries should prioritization target? Pap. Reg. Sci. 2020, 99, 1367-1388. [CrossRef]

17. European Commission. Regional Innovation Scoreboard. Available online: https://ec.europa.eu/growth/industry/policy/ innovation/regional_en (accessed on 22 September 2021).

18. Etzkowitz, H.; Leydesdorff, L. The dynamics of innovation: From National Systems and "Mode 2" to a Triple Helix of universityindustry-government relations. Res. Policy 2000, 29, 109-123. [CrossRef]

19. Carayannis, E.G.; Barth, T.D.; Campbell, D.F. The Quintuple Helix innovation model: Global warming as a challenge and driver for innovation. J. Innov. Entrep. 2012, 1, 2. [CrossRef]

20. Carayannis, E.; Grigoroudis, E. Quadruple Innovation Helix and Smart Specialization: Knowledge Production and National Competitiveness. Foresight STI Gov. 2016, 10, 31-42. [CrossRef]

21. Howells, J. Innovation and regional economic development: A matter of perspective? Res. Policy 2005, 34, 1220-1234. [CrossRef]

22. Crescenzi, R.; Rodríguez-Pose, A. Theoretical framework: A spatial perspective on innovation and the genesis of regional growth In Innovation and Regional Growth in the European Union; Crescenzi, R., Rodríguez-Pose, A., Eds.; Springer: Berlin/Heidelberg, Germany, 2011; pp. 9-29.

23. Pellegrini, G.; Terribile, F.; Tarola, O.; Muccigrosso, T.; Busillo, F. Measuring the effects of European Regional Policy on economic growth: A regression discontinuity approach. Pap. Reg. Sci. 2013, 92, 217-233. [CrossRef] 
24. Ferrara, A.R.; McCann, P.; Pellegrini, G.; Stelder, D.; Terribile, F. Assessing the impacts of Cohesion Policy on EU regions: A non-parametric analysis on interventions promoting research and innovation and transport accessibility. Pap. Reg. Sci. 2017, 96, 817-841. [CrossRef]

25. Wamser, G.; Woon, N.C.; Schoenberg, A. The Lisbon Agenda and Innovation-oriented Cohesion Policy: A New Challenge for Economic Integration among the EU Regions. J. Econ. Integr. 2013, 28, 37-58. [CrossRef]

26. Kaufmann, A.; Wagner, P. EU regional policy and the stimulation of innovation: The role of the European Regional Development Fund in the objective 1 region burgenland. Eur. Plan. Stud. 2005, 13, 581-599. [CrossRef]

27. Barca, F. An Agenda for a Reformed Cohesion Policy. In A place-Based Approach to Meeting European Union Challenges and Expectations; European Commission; DG Regio: Brussels, Belgium, 2009. Available online: https://ec.europa.eu/regional_policy/ archive/policy/future/pdf/report_barca_v0306.pdf (accessed on 1 September 2021).

28. Foray, D.; David, P.A.; Hall, B.H. Smart Spcialization: The concept. In Knowledge for growth. Prospects for Science, Technology and Innovation; Selected papers from Research Commissioner Janez Potočnik's Expert Group; Publications Office of the European Union: Luxembourg, 2009. Available online: https:/ / ec.europa.eu/invest-in-research/pdf/download_en/selected_papers_en. pdf (accessed on 1 September 2021).

29. Foray, D. On the policy space of smart specialization strategies. Eur. Plan. Stud. 2016, 24, 1428-1437. [CrossRef]

30. Johansson, B. Regional Competition: Endogenous and Policy-Supported Processes. In Regional Competition. Advances in Spatial Science; Batey, P.W.J., Friedrich, P., Eds.; Springer: Berlin/Heidelberg, Germany, 2000; pp. 34-65.

31. Porter, M. The Competitive Advantage of Nations: With a New Introduction; Macmillan Press: London, UK, 1991 , ISBN 0684841479.

32. Dicken, P. Global Shift: Mapping the Changing Contours of the World Economy, 7th ed.; University of Manchester: Manchester, UK, 2014, ISBN 9781446282106.

33. Watkins, M.H. A Staple Theory of Economic Growth. Can. J. Econ. Polit. Sci. 1963, 29, 141-158. [CrossRef]

34. Altman, M. Staple theory and export-led growth: Constructing differential growth. Aust. Econ. Hist. Rev. 2003, 43, 230-255. [CrossRef]

35. Lengyel, I. Verseny és területi fejlődés. In Térségek Versenyképessége Magyarországon; JATEPress: Szeged, Hungary, 2003, ISBN 9634826989.

36. European Commission. National/Regional Innovation Strategies for Smart Specialisation (RIS3). 2014. Available online: https:/ /ec. europa.eu/regional_policy/sources/docgener/informat/2014/smart_specialisation_en.pdf (accessed on 10 September 2021).

37. European Commission. Towards RIS3 2.0: Enabling Conditions. Available online: https://errin.eu/sites/default/files/2019-10/ TowardsRIS32.0---EnablingConditions_MarekPrzeor.pdf (accessed on 29 September 2021).

38. Cohen, C. Reflections Guiding Smart Specialisation Strategies Impact Assessment-Smart Specialisation Platform; Publications Office of the European Union: Luxembourg, 2021. Available online: https://publications.jrc.ec.europa.eu/repository/handle/JRC124046 (accessed on 25 September 2021).

39. Tolias, Y. Guidance for S3 Governance in the Period 2021-2027; Joint Research Centre: Brussels, Belgium, 2019. Available online: https: / / s3platform.jrc.ec.europa.eu/documents /20125/271617/D2b-GuidanceForS3Governance-v1.pdf/84142867-165a0989-f244-9004bd6e42d7?version=1.1\&t=1619523057683 (accessed on 10 September 2021).

40. Lengyel, I. (Ed.) Az intelligens szakosodási stratégiák alapjai, különös tekintettel az egészségiparra. In Térségek Növekedése És Fejlő́ése; JATEPress: Szeged, Hungary, 2018; pp. 11-35.

41. Boden, M. RIS3 Implementation in Lagging Regions: Lessons from Eastern Macedonia and Thrace. Eur. Struct. Invest. Funds J. 2015, 51, 77-83.

42. Morisson, A.; Doussineau, M. Regional innovation governance and place-based policies: Design, implementation and implications. Reg. Stud. Reg. Sci. 2019, 6, 101-116. [CrossRef]

43. Perianez-Forte, I.; Wilson, J. JRC Science for Policy Reports. Entrepreneurial Discovery Process (EDP); Publications Office of the European Union: Luxembourg, 2021. Available online: https://publications.jrc.ec.europa.eu/repository/handle/JRC124405 (accessed on 2 November 2021).

44. Nemzeti Kutatási, Fejlesztési és Innovációs Hivatal: S3 Monitoring Jelentés 2014-2019; Internal Report; Nemzeti Kutatási, Fejlesztési és Innovációs Hivatal: Budapest, Hungary, 2019.

45. Havas, A.; Lajos, N. National System of Innovation in Hungary; 2007. Available online: https://mpra.ub.uni-muenchen.de/6716 1/1/MPRA_paper_67161.pdf (accessed on 20 September 2021).

46. Tudomány És Technológiapolitika. 2000. Available online: https://nkfih.gov.hu/hivatalrol/hivatali-kiadvanyok/tudomany (accessed on 29 September 2021).

47. Lippényi, T.; Imre, J.; Kleinheincz, F. A magyar regionális innovációs rendszer kialakítása. Területi Stat. 2005, 8, 57-79.

48. Havas, A.; Izsak, K.; Markianidou, P.; Radosevic, S. Comparative Analysis of Policy-Mixes of Research and Innovation Policies in Central and Eastern European Countries. Grincoh Work. Pap. Ser. 2015, 1-60. [CrossRef]

49. South Transdanubian Regional Development Agency Regional Innovation Strategy for South Transdanubia. 2004, pp. 1-20. Available online: https:/ / ec.europa.eu/growth/tools-databases/regional-innovation-monitor/policy-document/ris3-strategysouth-transdanubia (accessed on 23 September 2021).

50. Lengyel, B.; Leydesdorff, L. Regional Innovation Systems in Hungary: The Failing Synergy at the National Level. Reg. Stud. 2010, 45, 677-693. [CrossRef] 
51. Government of the Czech Republic. Strategy for Smart Specialisation of the Czech Republic (National RIS3 Strategy); Government of the Czech Republic, 2016. Available online: http://www.czech-research.com/rd-system/key-documents/ris3-strategy/ (accessed on 4 November 2021).

52. Cvijanović, V.; Griniece, E.; Gulyás, O.; Reid, A.; Varga, H. Stakeholder engagement through entrepreneurial discovery? Lessons from countries and regions in Central and Eastern Europe. Cogent Soc. Sci. 2020, 6, 1-16. [CrossRef]

53. Schulz, S. Ambitious or Ambiguous? The Implications of Smart Specialisation for Core-Periphery Relations in Estonia and Slovakia. Balt. J. Eur. Stud. 2020, 9, 49-71. [CrossRef]

54. The World Bank Group. Toward an Innovative Poland: The Entrepreneurial Discovery Process and Business Needs Analysis; The World Bank Group: Washington, DC, USA, 2015. Available online: https://www.worldbank.org/en/country/poland/publication/ entrepreneurial-discovery-process-poland (accessed on 4 November 2021).

55. Hassink, R.; Gong, H. Six critical questions about smart specialization. Eur. Plan. Stud. 2019, 27, 2049-2065. [CrossRef]

56. Foray, D. In response to 'Six critical questions about smart spezialisation'. Eur. Plan. Stud. 2019, 27, 2066-2078. [CrossRef]

57. Gianelle, C.; Guzzo, F.; Mieszkowski, K. Smart Specialisation: What gets lost in translation from concept to practice? Reg. Stud. 2019, 54, 1377-1388. [CrossRef]

58. Valdmaa, K.; Pugh, R.; Müür, J. Challenges with strategic placed-based innovation policy: Implementation of smart specialization in Estonia and Wales. Reg. Stud. 2020, 29, 681-698. [CrossRef]

59. Polónyi-Andor, K. Intelligens szakosodási stratégia: Monitoring és értékelés. In Regionális Innováció, Vállalkozás És Gazdasági Növekedés; Varga, A., Ed.; Pécsi Egyetem Közgazdaságtudományi Kar: Pécs, Hungary, 2020; pp. 89-101. ISBN 978-963-429-629-4.

60. Laranja, M.E.; Pinto, J.; Foray, H. Implementation of Smart Specialisation Strategies in Portugal: An Assessment; Publications Office of the European Union: Luxembourg, 2020. Available online: https://publications.jrc.ec.europa.eu/repository/handle/JRC121189 (accessed on 21 September 2021).

61. European Commission. Proposal for Common Provisions Regulation; European Commission: Brussels, Belgium, 2021.

62. Mazzucato, M. Mission-oriented innovation policies: Challenges and opportunities. Ind. Corp. Chang. 2018, $27,803-815$. [CrossRef]

63. Schot, J.; Steinmueller, W.E. Three frames for innovation policy: R\&D, systems of innovation and transformative change. Res. Policy 2018, 47, 1554-1567. [CrossRef]

64. Fellnhofer, K. Facilitating entrepreneurial discovery in smart specialisation via stakeholder participation within online mechanisms for knowledge-based policy advice. Cogent Bus. Manag. 2017, 4, 1296802. [CrossRef]

65. Chesbrough, H.W. Open Innovation: The New Imperative for Creating and Profiting From Technology; Harvard Business School Press: Boston, MA, USA, 2003, ISBN 9781578518371.

66. Schomberg, R. A vision of responsible research and innovationy. In A Vision of Responsible Research and Innovation; Owen, R., Bessant, J., Heintz, M., Eds.; John Wiley and Sons: Sussex, UK, 2013; pp. 51-74. ISBN 978-1-119-96636-4.

67. European Commission. Responsible Research and Innovation; Publications Office of the EU: Luxembourg, 2014. Available online: https://ec.europa.eu/programmes/horizon2020/en/h2020-section/responsible-research-innovation (accessed on 1 October 2021). 